\title{
ДЕЯКІ СИНТАГМАТИЧНІ ВІДНОШЕННЯ ПРИ ЗІСТАВЛЕННІ УКРАЇНСЬКИХ, АНГЛІЙСЬКИХ ТА ПОРТУГАЛЬСЬКИХ ЮРИДИЧНИХ ТЕРМІНІВ У ЗОБОВ'ЯЗАЛЬНОМУ ПРАВІ
}

Чайка О. I. Деякі синтагматичні відношення при зіставленні українських, англійських та португальських юридичних термінів у зобов'язальному праві.

У статті розглядаються деякі синтагматичні відношення між термінами української, англійської та португальської мов у сфері зобов'язального права у зіставленні. Синтагматичні відношення аналізуються у межах мінімальної синтаксичної одиниці в зазначених досліджуваних мовах та розрізняються за сполучуваністю та контекстом (лексичним i синтаксичним) та аспектами синтагматики (семантичним і граматичним).

Ключові слова: синтагматика, синтагматичні відношення, термін (c) О. І. Чайка, 2015. 


\section{СТРУКТУРА I СЕМАНТИКА МОВНИХ ОДИНИЦЬ}

зобов'язального права, лексичний / синтаксичний контекст, семантичний / граматичний аспект синтагматики.

Чайка О. И. Некоторые синтагматические отношения при сопоставлении украинских, английских и португальских юридических терминов в праве обязательств.

Данная статья нацелена на рассмотрение и анализ некоторых синтагматических отношений между терминами украинского, английского и португальского языков в сопоставлении. Синтагматические отношения единиц анализируются в пределах минимальной синтаксической единицы в определенных языках и различаются по контексту и в зависимости от соединения. Контекст бывает лексическим или синтаксическим, в то время, как предоставленные анализу аспекты синтагматики - семантические и грамматические.

Ключевые слова: синтагматика, синтагматические отношения, термин в праве обязательств, лексический / синтаксический контекст, семантический / грамматический аспект синтагматики.

Chaika O. I. Certain Syntagmatic Relations between Legal Terms of Obligation in the Ukrainian, English and Portuguese Languages.

The article focuses on the analysis of certain syntagmatic relations as linear relations between the legal terms of the Ukrainian, English and Portuguese languages in the area of law of obligations. The syntagmatic relations get analysed within the minimum syntactical unit to be further differentiated with view to the context and coordination. The context as presented herein anticipates, without limitation, a kind as follows: lexical, semantic, grammatical, linguistic and extra-linguistic.

Key words: syntagmatic relations, a legal term of obligations, lexical, semantic, grammatical, linguistic and extra-linguistic contexts.

Початок XXI століття відзначається плідним переосмисленням лінгвістичних знань, які на даному етапі розвитку мовознавчої науки поєднують отримані результати досліджень мовознавців попередніх поколінь та властивий сьогоденню антропоцентричний підхід до вивчення мовних явищ. При цьому до уваги береться не лише інтерпретація мови, структура та семантика, культура та історія етносів, психічні особливості мовців, когнітивна складова при аналізі досліджуваних одиниць на різних мовних рівнях, а також вияв їхніх особливостей у власне мовленні. Так, усе більше приваблює звернення до синергетичної концепції, яка сприяє повнішому та глибшому пізнанню складних явищ у мові та мовленні. Вивчення мовних і мовленнєвих явищ на перетині наук - лінгвістики та психології / когнітології / економіки / права - дає змогу дещо по-новому побачити взаємодію мовних елементів, a здійснення дослідження в зіставно-типологічному плані яскраво демонструє, як за допомогою інтегрованого та міждисциплінарного підходів до вивчення неблизькоспоріднених мов можна суттєво збагатити 
та удосконалити понятійний та дослідницький апарати лінгвістики.

Поряд 3 тим, у сучасному теоретичному мовознавстві незалежно від географії - Україна, Великобританія, Сполучені Штати Америки, Канада чи Австралія, Португалія або Бразилія, аналіз довідкових лінгвістичних видань, монографій, підручників, новітніх праць і досліджень призводить до переосмислення визначення сфери дії синтаксису як єдиного за концептуальною базою, звертаючись до диференціації об'єктів синтаксису, основних синтаксичних одиниць, що утворюють ядро та периферію синтаксичних досліджень. Як влучно зауважує А. Загнітко, ми живемо в оточенні синтаксичного плюралізму, що вже став нормою для науки [1]. Загальновідомим $\epsilon$ те, що синтаксис поєднує в собі цілу низку фундаментальних понять, 3-поміж яких можемо виокремити такі, як поняття про систему синтаксичних одиниць, типологію синтаксичних зв'язків, 3 одного боку, та семантикосинтаксичних відношень, з іншого, - синтаксичні значення, синтаксичні форми та синтаксичні категорії $[1 ; 3 ; 4 ; 7]$. При розмежуванні синтаксису «великого» і «малого» (С. Сорокін, С. Кубрякова, М. Кочерган, С. ТерМінасова, А. Мікоян), де в першому разі під фокусом дослідження перебуває побудова речення та/або надфразова єдність і власне текст (Г. Золотова, І. Арібжанова), а у другому - складні еквіваленти слів (А. Лучик, О. Долгова), тобто ті найдрібніші одиниці мови, нижче яких синтаксичне дослідження «опускатися» не може, у запропонованій статті пропонується розглянути деякі синтагматичні відношення між термінологічними одиницями при зіставленні юридичних термінів зобов'язального права в українській, англійській та португальській мовах.

Очевидним $\epsilon$ те, що коло синтаксичних одиниць у лінгвістиці не $\epsilon$ чітко визначеним. Більш того, паралельно відстежуються кілька підходів до трактування власне синтаксичної одиниці та іï ролі в мовленні. Так, деякі мовознавці, наприклад, Ю. Долгов, вважають, що сфера синтаксичних одиниць обмежується лише реченням. У той же час інші філологи наголошують на віднесенні синтаксичних одиниць до немодельованих лінійних одиниць мовлення, у результаті чого такі синтаксичні одиниці переходять під фокус і сферу дії лінгвістики тексту [6]. Водночас, вітчизняні науковці (Д. Ізаренков, І. Гальперін, Т. Ніколаєва) дотримуються думки, що коло синтаксичних одиниць потрібно розширювати, оскільки до його складу включаються і словосполучення, $\mathrm{i}$ речення, і складне синтаксичне ціле (надфразна єдність), й абзац, і текст. В останні часи в лінгвістиці все більшого поширення набуває визначення трьох синтаксичних одиниць: а) мінімальна синтаксична одиниця; ๑ О. І. Чайка, 2015. 
б) словосполучення; та в) речення [1]. До них прилягає складне синтаксичне ціле як конструктивний складник тексту. Усі три синтаксичні одиниці є відтворюваними, але в центрі синтаксису розміщується речення. Наприклад, В. Мігірін та ін. відносять словосполучення до сфери мовлення, пояснюючи такий підхід загальним тлумаченням речення i словосполучення, беручи до уваги ступінь їх корелятивності / некорелятивності. За А. Загнітком, словосполучення - це «бінарна одиниця, утворена шляхом валентних можливостей головного слова 3 метою номінації тієї чи тієї реалії», тоді як мінімальна синтаксична одиниця - це член речення або елемент словосполучення [1]. У нашій статті йтиметься про деякі синтагматичні відношення в межах мінімальної синтаксичної одиниці в українській, англійській та португальській мовах.

Синтагматичні відношення юридичного терміна в українській, англійській, португальській мовах - це його лінійні, контекстні зв'язки, інакше кажучи, це його сполучуваність. Загальновідомо, що синтагматика характеризується комбінаторикою значень. Синтагматичні відношення юридичних термінів зобов'язального права у трьох зіставлюваних мовах не $\epsilon$ виключенням. Зрозуміло, що кожен термін зобов'язального права поєднується не з будь-яким(и), а виключно з тим(и), з яким(и) він має спільні семантичні компоненти. 3 одного боку, виокремлюється така група українських, англійських і португальських термінів зобов'язального права, яким властива одинична сполучуваність: наприклад, укр. набувальна давність 'один із способів набуття права власності на майно' (пор. англ. usucapion та порт. usucapião 'набувна давність, узукапія'). Причому важливо зазначити, що лише в українській мові відстежується така одинична сполучуваність терміна, тоді як в англійській та португальській мовах відповідниками є однокомпонентні терміни зобов'язального права; укр. дієздатність особи (наприклад, фізичної / юридичної) 'здатність своїми діями набувати для себе цивільних прав i самостійно їх здійснювати, а також здатність своїми діями створювати для себе цивільні обов'язки, самостійно їх виконувати та нести відповідальність у разі їх невиконання' (пор. англ. capacity [of a person] і порт. capacidade [da pessoa]). При такому зіставленні українського, англійського та португальського термінів зобов'язального права знову особливість синтагматики в межах мінімальної синтаксичної одиниці підкреслюється іiі відмінністю від англійського та португальського термінів зобов'язального права щодо одиничності сполучуваності, тоді як англійський та португальський терміни capacity та capacidade, відповідно, виявляють інші властивості та здатність формувати синтагматичні відношення не лише 3 
термінологічною одиницею особа. Водночас, одиничність сполучуваності при синтагматичних відношеннях юридичних термінів зобов'язального права притаманна англійській мові: так, англ. a prenuptial agreement 'шлюбний договір' у зіставленні з укр. илюбний договір та порт. um contrato pré-nupcial 'шлюбний договір'. У такому разі слід звернути увагу на те, що, незважаючи на схожість i семантичну подібність англійського та португальського термінів на позначення зобов'язальних відносин, синтагматичні відношення між термінологічними одиницями належать до різних категорійних груп та семантично не $є$ повними відповідниками до укр. шлюбний договір. Це пояснюється тим, що сполучуваність термінів зобов'язального права в конкретному випадку можемо розглядати як контекст, причому мінімальним контекстом терміна вважається терміносполука. Так, в Україні шлюбний договір укладається між особами, які подали заяву про реєстрацію шлюбу, а також між подружжям (звідси юридичний термін зобов'язального права - шлюбний договір), тоді як власне контекст мінімальної синтаксичної одиниці в англійській та португальській мовах засвідчує екстралінгвальність терміна зобов'язального права - англ. a prenuptial agreement, де буквально прикметник prenuptial 'дошлюбний', та порт. um contrato pré-nupcial, де аналогічно 3 англійською прикметник pré-nupcial позначає ознаку до моменту укладення шлюбу (букв. порт. pré-nupcial 'дошлюбний'), оскільки такий договір укладається між особами до того, як вони стали подружжям. Отже, незважаючи на деяку схожість між зазначеними англійським та португальським термінами, синтагматика в межах мінімальної синтаксичної одиниці відрізняється. Англ. prenuptial поєднується лише 3 agreement, у результаті чого утворюється такий розмовний юридичний термін, поширений у мовленні, як а prenup (a prenup agreement). При аналізі синтагматичних відношень, беручи до уваги ядро та периферію термінологічних одиниць в англійській та португальській мовах, необхідно підкреслити, що власне ядро - англ. agreement та порт. contrato - можуть сполучуватися з іншими одиницями. Так, наприклад, пор. англ. a labour agreement 'трудова угода', порт. um contrato de trabalho 'трудовий договір'; англ. a sale and purchase agreement 'договір купівлі-продажу' та порт. um contrato de compra e venda 'т. с.'. 3 іншого боку, величезна кількість юридичних термінів зобов'язального права в українській, англійській та португальській мовах відзначаються надзвичайно широкою сполучуваністю. Так, пор. укр. особа та такі юридичні терміни, як фізична особа, юридична особа, малолітня особа, неповнолітня особа, дієздатна особа, недієздатна особа і т. ін.; англ. a person - a natural person, an () О. І. Чайка, 2015. 
individual person, a physical person, a legal person etc.; порт. ита pessoa - uma pessoa física, uma pessoa jurídica i т. iн.

Синтагматичні відношення між термінами зобов'язального права в українській, англійській та португальській мовах можуть розглядатися через призму контексту. Контекст може бути лексичним або синтаксичним, іноді ще розрізняють контекст ситуативний. Можна виокремити й такі аспекти синтагматичних відношень, як лінгвальний або екстралінгвальний, семантичний.

За лексичним контекстом синтагматичні відношення відіграють неабияку роль, оскільки є досить критичними при визначенні та виборі значення в разі полісемантичного терміна зобов'язального права. Слід зазначити: власне контекст $є$ тим оточенням, що сприяє розкриттю поняття терміна, виявленню особливостей плану змісту услід за планом вираження. Пор. укр. золота середина та золота акиія з англ. golden middle i golden share; укр. юридична фiрма та юридична особа, англ. law offices та a legal person / entity, порт. um escritório de advocacia та uma pessoa jurídica.

За синтаксичним контекстом під фокусом перебуває план змісту юридичного терміна зобов'язального права в зіставлюваних мовах, що зумовлений граматичною формою терміна-поширювача: наприклад, пор. укр. вимога юридичної особи та вимога до юридичної особи, а також відповідники в англійській мові - англ. requirements of a legal person (a) та requirements to a legal person (б), та requirements for a legal person (в). Справа в тім, що у випадку (б) вимоги висуваються безпосередньо до юридичної особи, а у випадку (в) - щодо створення / реєстрації юридичної особи (особи-підприємця, підприємства).

Окрім термінологічно зумовленого контексту, існує контекст ситуативний (дискурсивний), у межах якого на смисл повідомлюваного впливають характеристики комунікації (час, місце спілкування, учасники комунікативного акту): наприклад, англ. 'The company will be obliged to dispose of the assets once a relevant court ruling is passed' - букв. укр. 'Компанії доведеться продати активи відразу після прийняття судового рішення'; 'The most valuable assets of any business are the people' - укр. 'Найціннішим, що може бути у компанії, є ї̈ працівники'.

Звертаючись до таких аспектів синтагматики, як семантичний i граматичний, відзначимо, що граматичний аспект визначається здатністю певної частини мови (іменник, прикметник, дієслово і т. ін.) сполучатися 3 термінами, що належать до інших частин мови. За допомогою граматичної структури юридичного терміна української, англійської та португальської мов можна визначити план змісту полісемантичного терміна. Так,

$$
\text { -229- } \text { ๑ О. І. Чайка, } 2015 .
$$


наприклад, в англійській мові to make a contract відповідає укр. nidzomyвати договір / угоду, проте англ. to make a business dispose of relevant assets в українській відповідатиме примусити (змусити) компанію / підприємство продати свої активи; англ. to make a great lawyer - укр. стати прекрасним юристом. Семантичний аспект синтагматики покриває синтагматичні відношення між юридичними термінами зобов'язального права в досліджуваних мовах, що стосуються загальноприйнятого вжитку певних термінів за рахунок частотності використання в чітко визначених обставинах: укр. укласти угоду - англ. to enter into an agreement / to conclude an agreement, порт. entrar em um acordo, celebrar um contrato; укр. розірвати угоду - англ. to terminate an agreement, to rescind an agreement, порт. rescindir um contrato; укр. угода про співпрацю - англ. а cooperation agreement / a collaboration agreement, порт. acordo de cooperação / acordo de colaboração.

Зазначені та описані за допомогою прикладів синтагматичні відношення між юридичними термінами зобов'язального права в українській, англійській та португальській мовах у запропонованій статті однозначно не $\epsilon$ вичерпними. Більш того, кожен із вище продемонстрованих видів може бути окремим блоком дослідження не лише в межах однісї мови, а й у зіставленні з іншими. У науці певний час вважалося, що парадигматика - це сфера мови, а синтагматика - сфера мовлення, але згодом такий підхід було спростовано, оскільки і синтагматика, і парадигматика існують у мові й реалізуються в мовленні.

Отже, у системі синтаксичних одиниць послідовно протиставляються слово і словосполучення / термін та термінологічна сполука як об'єкти вивчення малого синтаксису та речення i термінологічна сполука (термінологічне ціле) як елементи великого i малого синтаксисів. У термінознавстві здебільшого у фокусі знаходяться теоретико-методологічні питання дослідження, зокрема юридичний та інші дискурси, синтагматичні відношення між юридичними термінами в зобов'язальному праві в українській, англійській та португальській мовах, інтерпретація семантико-синтаксичних відношень таких терміносполук у зіставлюваних мовах. Вихід на типологію синтаксичних зв'язків $\epsilon$ перспективним напрямком подальших досліджень.

\section{Література}

1. Загнітко А. П. Український синтаксис : теоретико-прикладний аспект : [монографія] / А. П. Загнітко. - Донецьк, 2009. - 137 с.

2. Лучик А. А. Природа і статус еквівалентів слова у мовній системі / А. А. Лучик // Мовознавство. - 2006. - № 5. - С. 95-99.

3. Лучик А. А. Словник еквівалентів слова української мови / А. А. Лучик. - К. : () О. І. Чайка, 2015. 
ВД «Києво-Могилянська академія», 2008. - 174 с.

4. Hopper P. J. Grammaticalization / P. J. Hopper, E. C. Traugott. - Cambridge, 1993. - 256 p.

5. Cabré M. T. Terminology : Theory, methods and applications / M. T. Cabré, J. C. Sager. - Amsterdam : Benjamins, 1999. - 260 p.

6. Trask R. L. Key Concepts in Language and Linguistics / R. L. Trask. - London : Routledge, 1999. - 400 p.

7. Wüster E. Das Worten der Welt, schaubildlich und terminologisch dargestellt / E. Wüster // Sprachforum 60. - 1959. - 3/4: 183-203.

Стаття надійшла до редакиії 29.07.2015 p. 